J. AMER. Soc. Hort. SCI. 117(1):174-180. 1992.

\title{
Gene Transfer Using Electric Discharge Particle Bombardment and Recovery of Transformed Cranberry Plants
}

\author{
Rodney Serres and Elden Stang \\ Department of Horticulture, University of Wisconsin-Madison, Madison, WI 53706
}

Dennis McCabe and David Russell

Agracetus Corporation, Middleton, WI 53562

Da n i e l M ah r

Department of Entomology, University of Wisconsin-Madison, Madison, WI 53706

Brent McCown

Department of Horticulture, University of Wisconsin-Madison, Madison, WI 53706

Additional index words. Vaccinium macrocarpon, kanamycin, B.t.k. crystal protein, -glucuronidase, microprojectile bombardment, blackheaded fireworm

\begin{abstract}
Genetic transformation of the American cranberry, Vaccinium macrocarpon Ait., was accomplished using electric discharge particle acceleration. Plasmid DNA containing the genes GUS ( $\beta$-glucuronidase), NPTII (neomycin phosphotransferase II), and BT (Bacillus thuringiensis subsp. kurstaki crystal protein) was introduced into stem sections, derived from in vitro cultures, that had been induced to form adventitious buds. The stage of development of these adventitious buds was critical for efficient initial expression. After exposure to electric discharge particle acceleration, stem sections were cultured on a solid-phase bud-inducing medium containing $300 \mathrm{mg} \mathbf{~ k a n a m y c i n / l i t e r}$. In addition, a thin overlay of $300 \mathrm{mg}$ kanamycin/liter in water was added to inhibit growth of nontransformed cells. Within 7 weeks, green shoots emerged amidst kanamycin-inhibited tissue. No escape (nontransformed) shoots were recovered, and $90 \%$ of the transformed shoots were shown through PCR and Southern blot analysis to contain all three introduced genes. GUS expression varied markedly among various transformed plants. Preliminary bioassays for efficacy of the $B T$ gene against the feeding of an economically important lepidopteran cranberry pest have shown no consistently effective control. Potential problems with the expression of the BT and GUS genes are discussed
\end{abstract}

The American cranberry is a woody, low-growing perennial vine native to North America and found growing in temperate lowland marsh areas. The cranberry industry is important in the few states that have conditions conducive to its culture. Economically, cranberry is the most valuable fruit crop in both Wisconsin and Massachusetts.

Despite improvements in cranberry cultural practices, including the use of integrated pest management (Roper and Planer, 1989; Wis. Agr. Stat. Serv., 1989), insect and weed pests still account for significant losses in yield, and control of these pests has been estimated to account for $\approx 45 \%$ of the grower's direct field costs. Substantial amounts of carbamate and organophosphate insecticides are used throughout the growing season for insect control in cranberry marshes (Mahr et al., 1988).

Genetic transformation technology is being applied to cranberry with the goal of increasing productivity while reducing the potential environmental impacts of cranberry production in sensitive wetland areas. Successful transformation of other fruit crops, including strawberry (Fragaria $\times$ annanassa) (Nehra et al., 1990), apple (Mahs pumila Mill.) (James et al., 1989), Rubus spp.) (Graham et al., 1990), and orange (Citrus sinensis Osh.) (Kobayashi and Uchimiya, 1989), has been reported; however, we found no reports of the incorporation of an eco-

Received for publication 14 June 1991. Accepted for publication 10 Sept. 1991. This research was supported by the Wisconsin Cranberry Board and the Agricultural Research Station, College of Agriculture and Life Sciences, Univ. of Wisconsin-Madison. Mention of trade names is for the convenience of the reader and does not constitute endorsement by the Univ. of Wisconsin or Agracetus Corp. The cost of publishing this paper was defrayed in part by the payment of page charges. Under postal regulations, this paper therefore must be hereby marked advertisement solely to indicate this fact. nomically important foreign gene in a perennial fruit crop or of successful transformation of any members of the Ericaceae, to which the cranberry belongs.

An economically important gene of interest for cranberry is the Bacillus thuringiensis subsp. kurstaki crystal protein gene, $B T$, potentially conferring lepidopteran insect resistance (Vaeck et al., 1987). This gene has been most notably incorporated into tomato (Lycopersicon esculentum Mill.) (Fischhoff et al., 1987), but it has also proven to be effective in the woody perennial Populus (McCown et al., 1991). Commercially available Bacillus thuringiensis (B.t.) spore suspension sprays are registered for use on cranberry and other fruit crops (Chemical and Pharmaceutical Press, 1991). There are several B.t. crystal proteins that vary with the B.t. strain producing them. These are specifically effective against certain classes of insects, and there are few reports of toxicity to organisms other than insects (Andrews et al., 1987).

A plasmid containing the genes $B T, N P T I I$, a selectable marker for kanamycin resistance, and GUS, a reporter gene coding for $\beta$-glucuronidase, has been successfully introduced into cranberry stem tissue using electric discharge particle acceleration, a form of microprojectile bombardment (McCabe et al., 1988). Transformation of poplar (McCown et al., 1991) and spruce [Picea glauca (Moench) Voss] (Ellis et al., 1991) trees has been achieved in our laboratory using this system as well. Microprojectile bombardment has also been used successfully to transform other economic plants (Finer and McMullen, 1990; GordonKamm et al., 1990; Klein et al., 1988; McCabe et al., 1988).

Abbreviations: BIM, bud induction medium; CMM, cranberry micropropagation medium. 


\section{Materials and Methods}

Initiation and maintenance of shoot cultures. Stem sections of 'Stevens' cranberry were excised from field-grown plants, disinfected, and isolated on CMM, which is woody plant medium (Lloyd and McCown, 1981) containing 0.13\% D-gluconic acid, 0.3\% agar (Sigma, St. Louis), 0.1\% gelrite (Scott, Fiskeville, R.I.), $2 \%$ sucrose, and $0.1 \mu \mathrm{M} 2 \mathrm{ip}$ ( $\mathrm{N}^{6}$-[2-isopentenyl] adenine). Nodal stem sections were subculture to fresh CMM in Magenta GA7 boxes (Magenta Corp., Chicago) monthly. Axillary bud development and shoot elongation occurred under continuous light provided by cool-white fluorescent lamps (75 $\mu \mathrm{mol} \cdot \mathrm{m}^{-2} \cdot \mathrm{s}^{-1}$ at plant level) and at $25 \pm 3 \mathrm{C}$. Cultures were maintained for 1 year to assure stabilization.

Adventitious bud induction. In preparation for transformation, in vitro-derived stems were deleafed and divided into one-node stem sections $\approx 5 \mathrm{~mm}$ long with the node at the distal end. These stem sections were placed horizontally on BIM, which is CMM containing $1 \mu \mathrm{M}$ thidiazuron and $10 \mu \mathrm{M}$ 2ip instead of $0.1 \mu \mathrm{M}$ 2 ip. Twenty stem sections were evenly distributed in $60 \times 15$ $\mathrm{mm}$ disposable petri plates (Falcon, Lincoln Park, N.J.), and the plates were sealed with Nescofilm (Karlan, Santa Rosa, Calif.) to maintain high uniform humidity. Prebombardment treatments on this medium lasted for up to 20 days under conditions similar to those for shoot elongation.

Bombardment. After pretreatment, the stem sections were transferred to fresh BIM containing $500 \mathrm{mg}$ carbenicillin and $150 \mathrm{mg}$ benlate/liter (added to control contamination during bombardment) in $60 \times 15 \mathrm{~mm}$ disposable petri plates, hereafter called the target plates. About 12 stem sections were positioned horizontally to fill a $1-\mathrm{cm}^{2}$ area in the middle of the target plate. Transformation was performed using electric discharge particle acceleration (Christou et al., 1990) where microscopic gold particles coated with plasmid DNA are propelled into target tissue by the force of an electric discharge. We are terming the transformation procedure as "bombardment" and the treated stem sections as being "bombarded." The discharge voltage used was $16 \mathrm{kV}$, the vacuum drawn in the bombardment chamber was $300 \mathrm{~mm} \mathrm{Hg}$, and the DNA was loaded at a rate of $0.5 \mu \mathrm{g}$ DNA/mg of gold particles. Each target plate was bombarded with $75 \mu \mathrm{g}$ of DNA-coated gold particles.

Introduced DNA. The plasmid DNA coating the microprojectiles and pTVBTGUS (Fig. 1) has been described in detail by McCown et al. (1991). It contains the NPTII gene encoding neomycin phosphotransferase II, thus conferring resistance to the antibiotic kanamycin (Boehringer \& Mannheim, Germany), the GUS gene, which codes for B-glucuronidase, allowing a blue histochemical reaction in expressing tissue or cells, and the $B T$ gene, potentiating insect resistance. NPTII is regulated by the nopaline synthase (nos) promoter, while $G U S$ and $B T$ are regulated by CaMV $35 \mathrm{~S}$ promoters. All three genes are terminated by the nopaline synthase polyadenylation region.

Initial gene expression. Forty-eight hours after bombardment, randomly selected stem sections from each treatment were chosen for the $\beta$-glucuronidase histochemical assay, testing for expression of the GUS gene (Jefferson, 1987). Stem sections were transferrred to single wells of a 24-well culture plate (Corning, Coming, N. Y.) and bathed in the X-glucuronide (Clonetech, Palo Alto, Calif.) reaction mixture for $24 \mathrm{~h}$ at room temperature. After $24 \mathrm{~h}$, the reaction mixture was removed and the stem sections were rinsed twice with sterile distilled water before being covered with lactophenol for clearing. The number of blue spots per stem section was then counted to determine

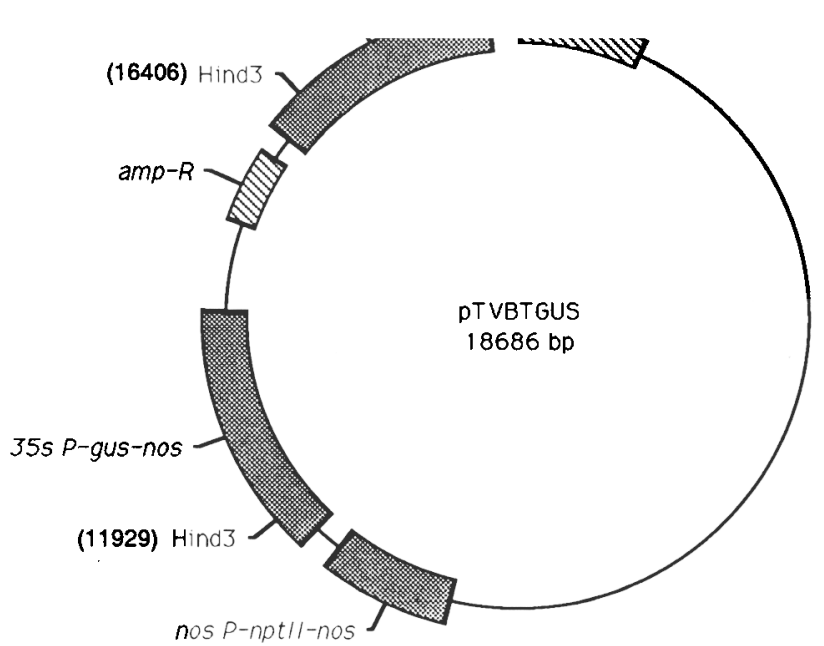

Fig. 1. HindIII restriction map of pTVBTGUS. The plasmid is composed of sulfadiazene-resistant vector RSF1010, a chimeric NPTII gene, a chimeric GUS gene, an ampicillin-resistant plasmid pMT21, and a chimeric $B T$ gene. Both $G U S$ and $B T$ are transcriptionally controlled by CaMV $35 \mathrm{~S}$ promoters, while NPTII has a nopaline synthase promoter.

initial gene expression rates. Blue spots often consisted of multiple cells with a definite center.

To determine the number of days of bud induction treatment required before bombardment that would give optimum initial foreign gene expression, nine lengths of pretreatment times were investigated. Three BIM plates were prepared with stem sections as described, but on succeeding days, so that a single day was used for bombarding all treatments. From the 60 bud-induced stem sections for each treatment, three target plates were set up, using about two-thirds of the pretreated stem sections. When selecting target stem sections, preference was given in all treatments to those showing the most development. After bombardment, 25 stem sections for each treatment were histochemically assayed for GUS as described. The mean and SE of blue spots per stem section in each treatment were calculated. This experiment was repeated two times.

Antibiotic selection. Based on results from the experiments outlined above, the bombardment protocol, as described and with a 16-day bud-inducing pretreatment, was used to obtain 207 bombarded single-node stem sections. Five of these stem sections were randomly chosen for the GUS histochemical assay 2 and 50 days after bombardment. Bombarded stem sections not assayed for GUS were carried through a four-stage selection system: Stage 1, 2 days after bombardment, stem sections were transferred to BIM containing $300 \mathrm{mg}$ kanamycin/liter in 100$\mathrm{ml}$ baby food jars capped with Magenta B-caps. Stage 2, 3 weeks after bombardment, a 5-ml liquid overlay of $300 \mathrm{mg}$ kanamycin/liter of sterile water $(\mathrm{pH} 5.6$ adjusted with $\mathrm{HCl})$ was added to the surface of the solid medium, bathing, but not entirely submerging, all of the stem sections. Stage 3, 11 weeks after bombardment, stem sections were transferred to solidified CMM plus $300 \mathrm{mg}$ kanamycin/liter in Magenta GA7 boxes. Nine days after being transferred to the GA7s, these sections were again nearly submerged with a 10-ml overlay of $200 \mathrm{mg}$ kanamycin/liter of sterile water. Stage 4, 22 weeks after bombardment, stem sections were transferred to fresh CMM with neither the addition of kanamycin in the medium nor kanamycin 
as an overlay. Any elongated putatively transformed shoots were isolated from Stages 2, 3, and 4 and transferred to CMM in GA7 boxes for multiplication.

Confirmation of transformation and gene expression. Histochemical assays for GUS expression were performed as described above on whole shoot tips, cut leaves, roots, transverse leaf sections $\approx 50 \mu$ thick, and transverse stem sections $\approx 125$ $\mu$ thick of selected plants grown in a greenhouse or in vitro. Thin sections were made with a vibratome (model G, Oxford Laboratories St. Louis) in sterile distilled water. Newly cut sections were immediately moved to $\mathrm{X}$-glucuronide reaction mixture.

Polymerase chain reaction (PCR) was used to analyze all putatively transformed regenerates for the presence of the three introduced foreign genes. Stem and leaf tissue $(\approx 5 \mathrm{mg})$ were used for DNA extraction (Dellaporta et al., 1983). About 100 ng of genomic DNA was used for each PCR amplification under standard conditions (Saiki et al., 1988). Three sets of PCR primers were used to detect unique portions of the introduced DNA: 1) For NPTII the amplified product was $135 \mathrm{bp}$ of the $5^{\prime}$ portion of the NPTII coding region; 2) for GUS, the amplified product was a 710-bp portion from the $5^{\prime}$ region of the GUS gene; 3 ) for $B T$, the amplified product was a 703-bp portion from the middle of the gene. To confirm the results for the $B T$ gene, two additional sets of PCR primers were used: for the $5^{\prime}$ region of $B T$, the amplified product contained the $64 \mathrm{bp}$ of the CaMV $35 \mathrm{~S}$ promoter and the first $640 \mathrm{bp}$ of the $B T$ coding region; and for the $3^{\prime}$ region of $B T$, the amplified product contained $515 \mathrm{bp}$ of the $3^{\prime}$ portion of $B T$ and $30 \mathrm{bp}$ of the nos termination sequence.

Southern blotting was performed on several regenerates to confirm presence of the $B T$ gene in the transgenic cranberry DNA. The DNA was isolated by a modification of the procedure of Dellaporta et al. (1983). Modifications included removing RNA and proteins by RNase A digestion and phenol-chloroform extraction. Southern blot analysis was performed as described by Christou et al. (1989).

Transformation efficiency. Research on the genetic transformation of several woody plant species in our laboratory has led to the use of a few working definitions that describe different phases of gene expression. Transformation refers to the incorporation of the introduced DNA into the plant genome. Longterm expression refers to expression of the introduced genetic element for an extended period of time after bombardment (50 days for this study). The expression may be characterized as individual blue cells, groups of cells, or entire blue tissues. Initial expression refers to the expression that is evident within the first 2 weeks after bombardment. This phase is primarily composed of transient gene expression that will eventually be lost, but also includes those cells that will exhibit long-term expression and regenerate into transformed plants. We use the term transclone to refer to the population of shoots arising and cloned from a unique transformation event. All vegetatively propagated plants derived from an original transformed regenerated shoot are the same transclone.

The long-term expression rate was determined by dividing the average number of individual cells or groups of cells expressing the GUS gene after 50 days by the average number of blue spots 2 days after bombardment (initial expression) and multiplying by 100 to get a percentage. Recovery efficiency was determined by dividing the number of transclones by the estimated number of initial blue spots 2 days after bombardment (initial expression) and multiplying by 100 to get a percentage.
Acclimation. Verified transclones were maintained and multiplied in vitro on CMM. Elongated shoots were harvested and inserted directly into plasticized peat plugs (Grow-Tech, Watsonville, Calif.) held in a clear plastic box for rooting and acclimation under fluorescent lights (continuous at $\approx 80$ $\mu \mathrm{mol} \cdot \mathrm{m}^{-2} \cdot \mathrm{s}^{-1}$ at plant level). Once roots had developed, plantlets were acclimated by gradually opening the plastic lid. After acclimation to laboratory relative humidity (20\%-60\%), plantlets were placed under a high intensity discharge lamp with 200 $\mu \mathrm{mol} \cdot \mathrm{m}^{-2} \cdot \mathrm{s}^{-1}$ at plant level (Energy Technics, York, Pa.) and fertilized monthly.

Insect feeding bioassay. A bioassay screen was designed to identify those transclones effectively expressing the $B$. $t$. crystal protein. Effective expression was defined as the death of all or nearly all larvae that fed on the transclone shoots. Laboratoryacclimated shoots $\approx 5 \mathrm{~cm}$ long were placed in individual petri plates with a moist falter paper. Blackheaded fireworm (BHFW), Rhopobota naevana (Hubner), eggs were harvested in the autumn on commercially grown cranberry vines from one marsh and stored in a $4 \mathrm{C}$ chamber for $\approx 3$ months. The egg-containing vine cuttings were removed from cold storage and individual leaves containing the eggs were isolated for incubation and hatching at $28 \mathrm{C}$. Upon hatching ( $\approx 1$ week), the larvae were stored in a 4C chamber until enough were collected for our needs (maximum of 3 days). To begin the bioassay, a single first instar BHFW larva was placed on the test shoot near the shoot tip. Eight transclones and a nontransformed control were tested with five shoots per treatment. Tests were conducted individually in $90 \times 15 \mathrm{~mm}$ disposable petri plates with moistened filter paper on the bottom, within a growth chamber at a constant $28 \mathrm{C}$ and an 18-h light : $6 \mathrm{~h}$ dark cycle. The larvae were maintained on test tissue until they either died or pupated. New shoots of the same transclone or control were added when the original shoot was completely devoured. If a larva died before reaching its last instar, a new first instar larva was placed on the same shoot. Percent mortality of the total number of larvae added, life cycle stage when they died, and time to pupation were recorded.

\section{Results and Discussion}

Multiplication through axillary-derived shoots resulted in stable production of morphologically homogeneous shoots after more than 1 year in continuous culture and, thus, allowed production of uniform material for bombardment experiments. Axillary budbreak occurred on $\approx 90 \%$ of the single-node stem sections isolated for multiplication. Axillary-derived shoots elongated to $7 \mathrm{~cm}$ in 4 weeks and were composed of $\approx 12$ nodes. Branching of the axillary-derived shoots seldom occurred until the shoot reached the top of the vessel, $\approx 5$ to 6 weeks after subculture.

Adventitious buds were induced on internode or nodal stem sections when cultured on BIM (Fig. 2). Buds were visible after 10 days of culture and continued to enlarge and develop. Secondary adventitious buds commonly arose from these existing buds within $\approx 20$ days. After $\approx 30$ days on BIM, shoot elongation occurred from many of the buds. The elongation of a shoot appeared to inhibit further development of other buds near that shoot.

Foreign gene expression, assayed $48 \mathrm{~h}$ after bombardment, was evident by the histochemical assay for the GUS gene (Fig. 3 ). Initial gene expression rates increased as bud development progressed and were highest in tissues treated 16 days on BIM. At this time, adventitious buds were well developed and small leaves were just visible (Fig. 4). With periods of bad induction 


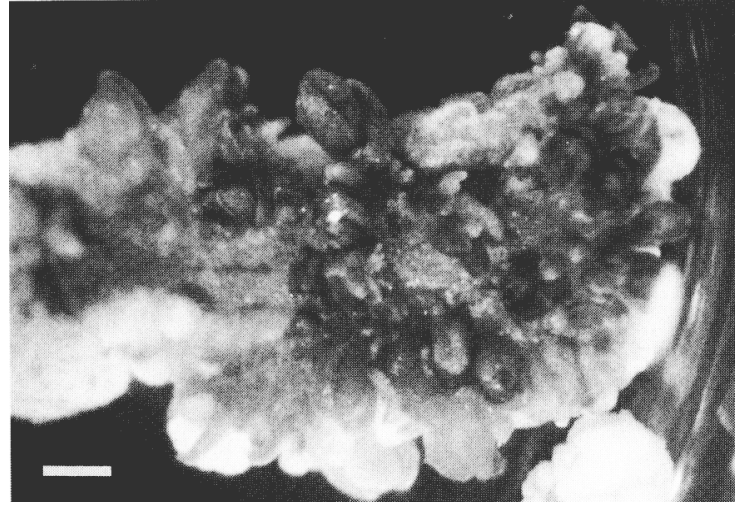

Fig. 2. Adventitious buds generated on a single-node cranberry stem section after 18 days on BIM. The length bar represents $0.5 \mathrm{~mm}$.

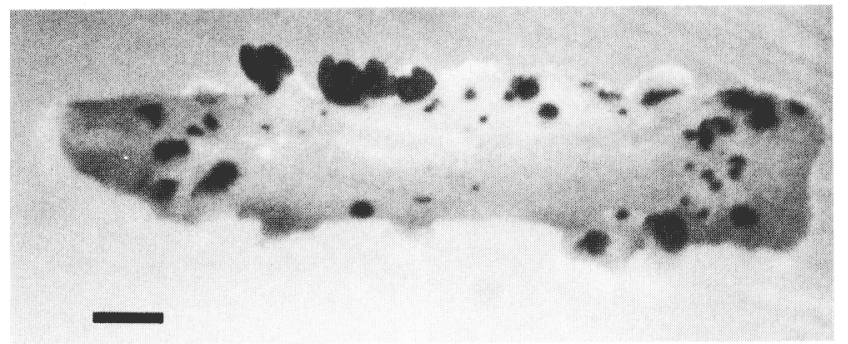

Fig. 3. Expression of the GUS gene (dark spots) indicating transformed cells along a bombarded cranberry stem section pretreated on BIM for 16 days before bombardment. The histochemical assay was conducted 2 days after bombardment. The length bar represents $0.5 \mathrm{~mm}$.

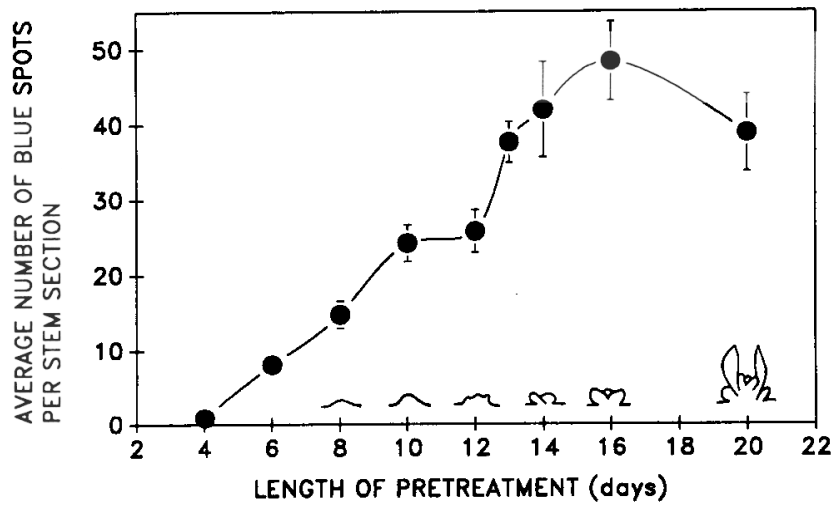

Fig. 4. Effect of length of time of tissue pretreatment on initial expression of the GUS gene in single-node stem sections of cranberry. Drawings along $\mathrm{X}$-axis represent stages of adventitious bud development prevalent at that length for pretreatment. Vertical bars represent SE for 25 stem sections. The experiment was conducted twice.

longer than 22 days, initial gene expression continued to decrease (data not shown). The same length-of-bud-induction experiment, but with a different cultivar, gave similar results, suggesting the strong influence of the state of adventitious bud development on the number of visible initial expression events.

During Stage 1 of the selection system described in the Materials and Methods section, the stem sections remained green, but little further development was evident. Within 2 weeks after the overlay of Stage 2 was added, most buds began to turn pale green to yellow with little to no growth. After 3 weeks of Stage
2 , the first regenerate was evident-a green shoot arising from a green bud amidst yellow-gray nontransformed buds (Fig. 5). After all bombarded stem sections were moved to Stage 3 medium, more regenerates appeared, with a total of 11 regenerated shoots after 26 weeks of monthly transfers to fresh Stage 3 or Stage 4 medium. Nonbombarded control tissue was also subjected to the selection system and no shoots were regenerated.

Initial experiments without a kanamycin overlay were hampered by escape tissue (rapidly dividing and developing nontransformed tissue) even with $300 \mathrm{mg}$ kanamycin/liter in the solid medium. This result suggests poor translocation of kanamycin through the plant tissue and the need for better contact of the tissue with the kanamycin. The liquid overlay provided the needed contact and inhibited growth of nontransformed tissue. The 3 weeks before the overlay allowed recovery from bombardment and development of adventitious buds on the upper (bombarded) surface of the stem sections. Three weeks after the overlay was applied, it was evident that nontransformed tissues had stopped normal growth at the time of the overlay while transformed tissues had continued to develop.

After 26 weeks, all possible regenerated shoots were recovered from the selection system. Figure 6 shows the transformation efficiency obtained in this experiment using electric discharge particle acceleration. Initial gene expression assayed after 2 days revealed an average of 38 blue spots per stem section, and long-term expression assayed at 50 days after bombardment had an average of 13 spots per stem section. Longterm expression was $\approx 66 \%$ less than the initial expression, and $0.15 \%$ of the initial cells expressing GUS differentiated into transformed meristems and subsequently shoots.

The number of blue spots representing GUS expression drops over time but reaches a relatively steady number after 5 weeks (data not presented). Ellis et al. (1991), working with spruce tree embryos, and Sellmer et al. (1990), working with poplar tree cell suspensions, reported a similar trend of a drop-off of the number of GUS-expressing cells 1 to 3 weeks after bombardment (depending on the plant species) followed by a baseline lower level of expression.

PCR analysis of several regenerated shoots, after five subcultures using axillary shoot multiplication, showed the presence of all three introduced genes (Table 1). Expression of the GUS gene was verified through histochemical assays on selected shoots, and expression of this gene was highly variable within and among transclones. No transclone showed a strong, consis-

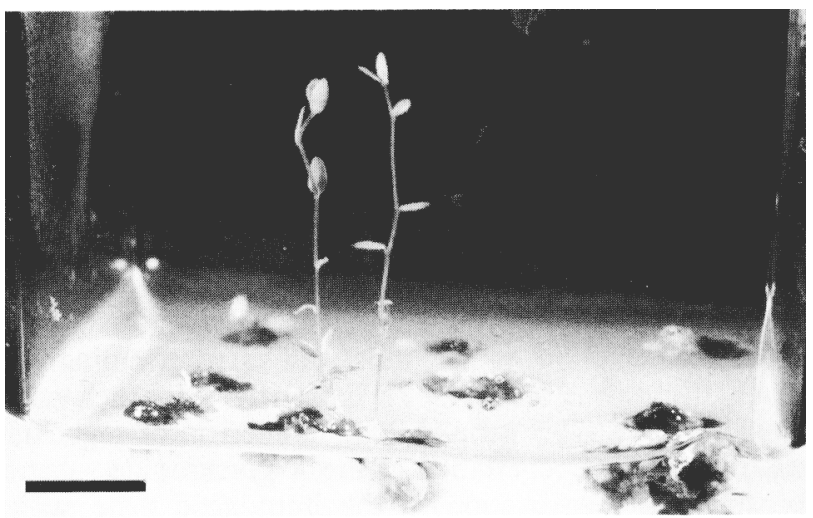

Fig. 5. A transformed cranberry shoot growing from a bombarded stem section under kanamycin selection. Strongly inhibited tissues are also evident in the culture vessel. The length bar represents 10 $\mathrm{mm}$. 


\section{Percentage of total GUS spots}

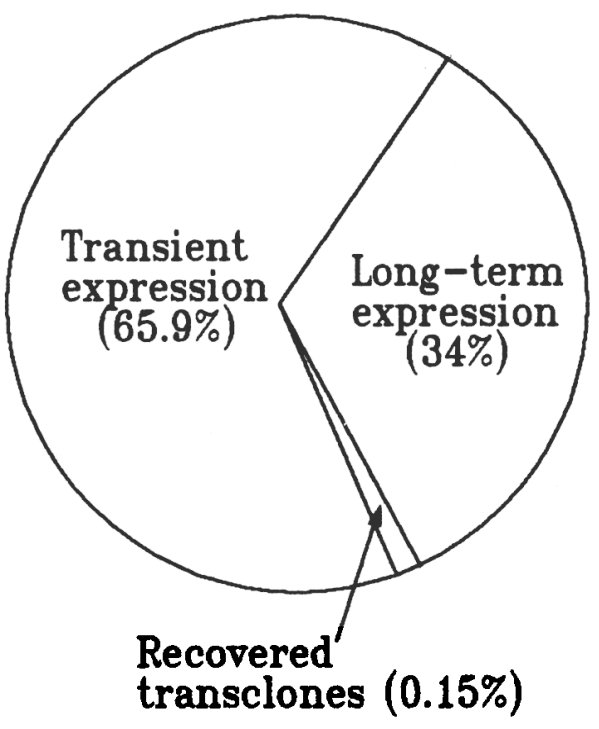

Fig. 6. Tranformation efficiency using electric discharge particle bombardment on cranberry stem sections. The GUS histochemical assay was used to determine transient and long-term efficiencies, and kanamycin resistance was used to select for recoverable transclones. Percentages are based on the total number of initial blue spots.

Table 1. Presence and expression of NPTII GUS, and BT in regenerated cranberry shoots after electric discharge particle acceleration. ${ }^{2}$

\begin{tabular}{|c|c|c|c|c|c|c|c|}
\hline \multirow[b]{3}{*}{ Transclone } & \multicolumn{7}{|c|}{ Gene presence } \\
\hline & \multicolumn{3}{|c|}{ PCR } & \multirow{2}{*}{$\frac{\text { Southern }}{\text { BT }}$} & \multicolumn{3}{|c|}{ Gene expressiony } \\
\hline & NPTII & GUS & BT & & NPTII & GUS & BT \\
\hline BtSt 11 & + & + & + & + & + & + & - \\
\hline BtSt 12 & + & + & + & 0 & + & + & - \\
\hline BtSt 13 & + & + & + & + & + & - & - \\
\hline BtSt 14 & + & + & + & + & + & + & - \\
\hline BtSt 15 & + & - & - & 0 & + & - & - \\
\hline BtSt 16 & + & + & + & + & + & - & - \\
\hline BtSt 17 & + & + & + & 0 & + & + & o \\
\hline BtSt 18 & + & + & + & 0 & + & + & 0 \\
\hline BtSt 19 & + & + & + & + & + & + & - \\
\hline BtSt $20^{\circ}$ & + & + & + & + & + & + & - \\
\hline BtSt 21 & + & + & + & 0 & + & + & o \\
\hline Control & - & - & - & - & - & - & - \\
\hline
\end{tabular}

$\mathrm{z}_{\mathrm{o}}=$ no data taker; $+=$ strong evidence for presence/expression;

$-=$ no evidence for presence/no or weak evidence for expression.

${ }^{y}$ Gene expression was determined for $K A N$ by the presence of shoots growing through a kanamycin selection system, for GUS by the Bglucuronidase histochemical assay, and for $B T$ by a feeding trial with blackheaded fireworms.

tent blue pigmentation; rather, most had small, seemingly random areas that stained blue (Fig. 7). Explanations for such variable expression of the GUS gene include chimerism of regenerated plants, difficulty of penetration of the X-glucuronide substrate, post-insertional modification of the introduced gene such as methylation, post-translational modification of B-glucuronidase, and variation of the points of gene insertion among the transclones. We detected no visual evidence, such as sectoring or tissue-layer specific expression, for the presence of chimeric

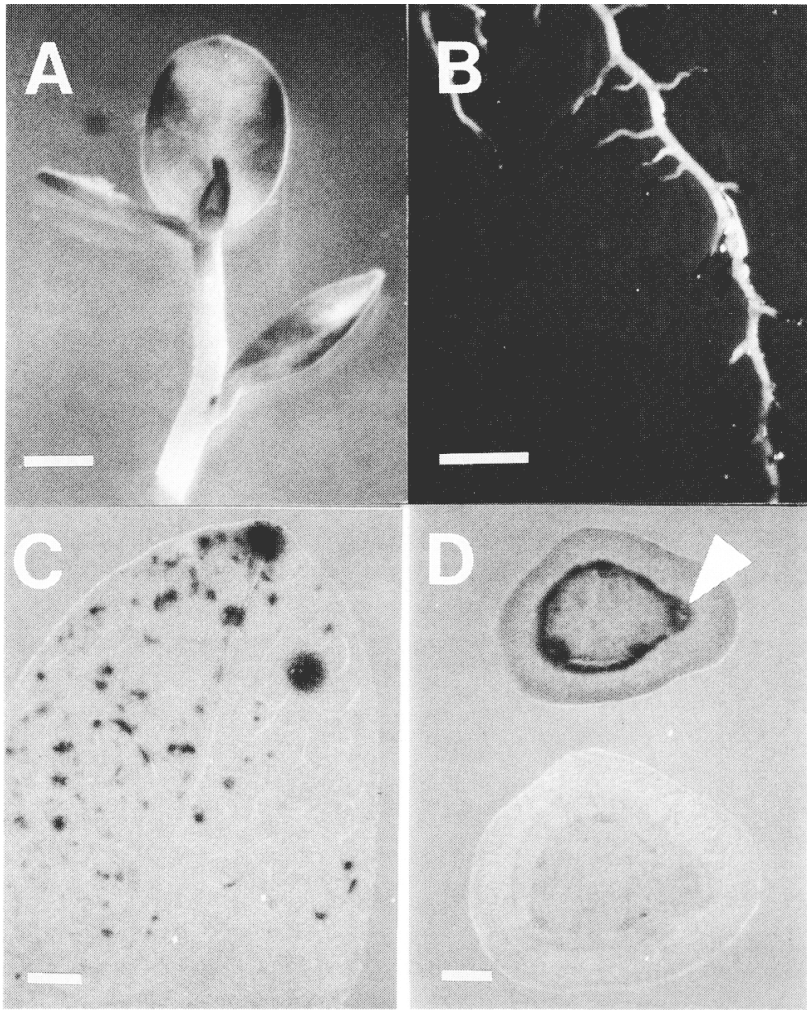

Fig. 7. Expression of the GUS gene (dark areas) in cranberry tissues cleared with lactophenol. (A) In vitro-grown BtSt 12 shoot tip showing large regions of expression. (B) BtSt 19 greenhouse-grown roots. (C) Greenhouse-grown BtSt 11 cleared leaf showing random and variable GUS expression. (D) Transverse stem sections of greenhouse-grown nontransformed control (bottom) and BtSt 19 (top). BtSt 19 shows a blue vascular cylinder and leaf trace (arrow). Length bars in (A) and (B) represent $2 \mathrm{~mm}$ and in (C) and (D) represent $200 \mu \mathrm{m}$.

regenerates. Thin sectioning revealed that penetration of the substrate was not the major reason for variable $G U S$ expression since precipitate patterns remained virtually the same in thin sections as uncut leaves. Therefore, the explanation of such variable expression of the GUS gene remains unclear.

Southern blotting for the presence of the $B T$ gene was performed on six transclones (Table 1). The cranberry DNA was digested with HindIII and then probed with a BT HindIII fragment from the input DNA vector pTVBTGUS. The expected size for an intact $B T$ fragment is $1.7 \mathrm{~kb}$ and was found for all of the clones analyzed by Southern hybridization (Fig. 8). The relative copy number appears to vary among the different transclones. BtSt11 and BtSt20 probably contain many copies but a precise number cannot be elucidated from these data. In no case was there a conflict between PCR and Southern blot data.

The insect-feeding bioassay did not reveal a convincingly BHFW-resistant transclone (Table 1); however, several of the transclones gave an indication of possible $B T$ expression. All but one of the transclones had an insect death associated with them, and no insect death was associated with the control nontransformed clone. However, time to pupation was consistent among all surviving larvae. Commercially available B.t. solutions have been tested on BHFW and effected $80 \%$ to $100 \%$ mortality. Thus, introduced resistance in cranberry to BHFW 


\section{$\begin{array}{llllll}1 & 2 & 3 & 4 & 5 & 6\end{array}$}

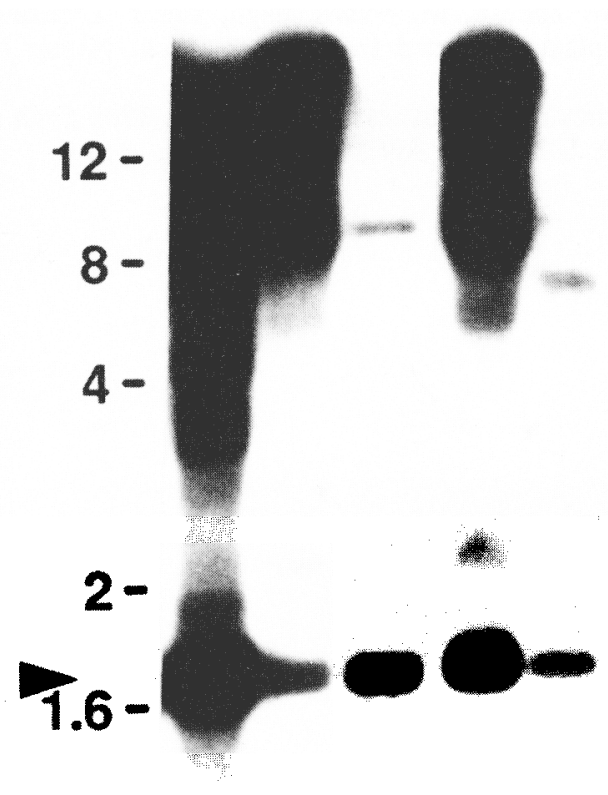

Fig. 8. Southern blot analysis of cranberry transclones. DNA was isolated from various transclones, digested with HindIII, transferred to nylon membrane, and probed with a BT HindIII fragment. The intact BT HindIII fragment is $\approx 1.7 \mathrm{~kb}$ (arrow). Lane 1, BtSt11; Lane 2, BtSt13; Lane 3, BtSt14; Lane 4, BtSt20; Lane 5, BtSt19; and Lane 6, nontransformed control 'Stevens' DNA. High molecular weight signals resulted from an incomplete digestion of the genomic DNA.

has not been effectively achieved. One hypothesis for these results is that the $B T$ gene may not be expressed at a high enough level or not in enough cells to inhibit insect development. Although $B$. $t$. formulations are used on cranberry for lepidopteran control, the specific effects of the pTVBTGUS plant-produced B.t.k protein on BHFW have not been documented, and relatively high levels of gene expression maybe needed for effective BHFW control. Interestingly, this same construct gave effective control of two lepidopteran insects in a poplar transclone (McCown et al., 1991).

The variable and generally low-level expression of both the $B T$ and GUS genes raised concerns about the CaMV 35s promoter used. Since all shoots that were regenerated through the selection system contained the NPTII gene, we assume that the nos promoter was effectively driving gene expression and therefore that not all foreign gene expression in cranberry is problematic. Different promoters driving the $G U S$ and $B T$ genes need to be tested to try to obtain stronger and more consistent expression.

Seven of the 11 transclones were morphologically variant in one or more characters from the control 'Stevens' plants. No variation has been observed from stock culture-derived plants. The variant traits, including growth rate, leaf size, leaf shape, and internode length, are consistently stable through repeated subcultures. During growth in the greenhouse the characteristics appeared to be stable. Whether this variation was a direct result of transformation or a result of the regeneration/selection system has not been discerned.

Pretreatment of the stem sections to attain competent tissue for transformation and an effective selection system were important factors in transformation success with cranberry. The electric discharge particle acceleration system provides an attractive alternative to Agrobacterium -mediated transformation and methods that require isolation of and regeneration from protoplasts. Because these techniques are not specific to cranberry and thus likely will be generally applicable over many crop species, the transformation system reported here may be useful for the genetic transformation of other crops, especially perennial fruit and ornamental plants.

\section{Literature Cited}

Andrews, R.E., R.M. Faust, H. Wabiko, and K.C. Raymond. 1987. The biotechnology of Bacillus thuringiensis. CRC Critical Reviews in Biotechnology 6(2):163-232.

Chemical and Pharmaceutical Press. 1991. Crop protection chemicals reference, 7th ed. Wiley, N.Y.

Christou, P., W.F. Swain, N.-S. Yang, D.E. McCabe. 1989. Inheritance and expression of foreign genes in transgenic soybean plants. Proc. Natl. Acad. Sci. USA 86:7500-7504.

Christou, P., D.E. McCabe, B.J. Martinell, and W.F. Swain. 1990. Soybean genetic engineering-commercial production of transgenic plants. Tibtech 8(6):145-151.

Dellaporta, S.L., J. Wood, and J.B. Hicks. 1983. A plant DNA minipreparation: version II. Plant Mol. Biol. Rpt. 1(4):19-21.

Ellis, D. D., D. McCabe, D. Russell, B. McCown, and B. Martinell. 1991. A transient assay for heterologous promoter activity in Picea glauca. In: M.R. Ahuja (ed.). Woody plant biotechnology. Plenum, New York. (In press.)

Finer, J.J. and M.D. McMullen. 1990. Transformation of cotton (Gossypium hirsutum L.) via particle bombardment. Plant Cell Rpt. 8:586 589.

Fischhoff, D.A., K. Bowdish, F. Perlak, P. Marrone, S. McCormick, J. Niedermeyer, D. Dean, K. Kusano-Kretzmer, E. Mayer, D. Rochester, S. Rogers, R. Fraley. 1987. Insect tolerant transgenic tomato plants. Bio/Technology 5:807-813.

Gordon-Kamm, W.J., T.M. Spencer, M.L. Mangano, T.R. Adams, R.J. Dairies, W.G. Start, J.V. O'Brien, S.A. Chambers, W.R. Adams, Jr., N.G. Willetts, T.B. Rice, C.J. Mackey, R.W. Krueger, A.P. Kausch, and P.G. Lemaux. 1990. Transformation of maize cells and regeneration of fertile transgenic plants. The Plant Cell 2:603-618.

Graham, J., R.J. McNicol, and A. Kumar. 1990. Use of the GUS gene as a selectable marker for Agrobacterium -mediated transformation of Rubus. Plant Cell Tissue Organ Cult. 20:35-39.

James, D.J., A.J. Passey, D.J. Barbara, and M. Bevan. 1989. Genetic transformation of apple (Malus pumila Mill.) using a disarmed Tibinary vector. Plant Cell Rpt. 7:658-661.

Jefferson, R.A. 1987. Assaying chimeric genes in plants: the GUS fusion system. Plant Mol. Biol. Rpt. 5(4):387-405.

Klein, T.M., E.C. Harper, Z. Svab, J.C. Sanford, M.E. Fromm, and P. Maliga. 1988. Stable genetic transformation of intact Nicotiana cells by the particle bombardment process. Proc. Natl. Acad. Sci. USA 85:8502-8505.

Kobayashi, S. and H. Uchimiya. 1989. Expression and integration of a foreign gene in orange (Citrus sinesis Osb.) protoplasts by direct gene transfer. Jpn. J. Genet. 64:91-97.

Lloyd, G. and B. McCown. 1981. Commercially feasible micropropagation of mountain laurel (Kalmia latifolia) by use of shoot tip culture. Proc. Intl. Plant Prop. Soc. 30:421-427. 
Mahr, D. L., S.N. Jeffers, E.J. Stang, and M.N. Dana. 1988. Cranberry pest control in Wisconsin. Univ. of Wisconsin, Serv. Bul. A3276:18p.

McCabe, D. E., W.F. Swain, B.J. Martinell, and P. Christou. 1988. Stable transformation of soybean (Glycine max) by particle acceleration. Biotechnology 6:923-926.

McCown, B. H., D.E. McCabe, D.R. Russell, D.J. Robison, K.A. Barton, and K.F. Raffa. 1991. Stable transformation of Populus and incorporation of pest resistance by electrical discharge particle acceleration. Plant Cell Rpt. 9:590-594.

Nehra, N. S., R.N. Chibbar, K.K. Kartha, R.S.S. Datla, W.L. Crosby, and C. Stuchnoff. 1990. Agrobactetium-mediated transformation of strawberry calli and recovery of transgenic plants. Plant Cell Rpt. 9:10-13.

Roper, T.R. and T.D. Planer. 1989. Cranberry production in Wiscon- sin. Wisconsin Cranberry Board Pub., Wisconsin Rapids, Wis.

Saiki, R.K., D.H. Gelfaud, S. Stoffel, S.J. Scharf, R. Higuchi, G.T. Horn, K.B. Mullis, and H.A. Erlich. 1988. Primer-directed enzymatic amplification of DNA with a thermostable DNA polymerase. Science 239:487-494.

Sellmer, J., D. Ellis, B. McCown, D. McCabe, and B. Martinell. 1990. Biological aspects of transforming suspension cells by electrical discharge particle acceleration. Plant Physiol. 93:168 Suppl. (Abstr.)

Vaeck, M., A. Reynaerts, H. Hofte, S. Jansens, M. DeBeuckeleer, C. Dean, M. Zabeau, M. VanMontagu, and J. Leemans. 1987. Transgenic plants protected from insect attack. Nature (London) 238:33-37.

Wisconsin Agricultural Statistics Service. 1989. 1988 Cash receipts. Pub. 200-89. U.S. Dept. Agr., Madison, Wis. 